\title{
Introduction: Wither the intelligentsia: the end of the moral elite in Eastern Europe
}

\author{
Serguei Alex. Oushakine
}

Published online: 19 November 2009

(C) Springer Science+Business Media B.V. 2009

As the editor of a book series devoted to translations of contemporary East European literature, I am frequently asked, "Why has no new Milan Kundera appeared in Eastern Europe since the collapse of communist regimes?"... I can say with some confidence that the sociocultural conditions that once allowed for the appearance of "Milan Kundera" no longer exist in most of postcommunist Eastern Europe, and they are unlikely to return in the near future. The disappearance of these conditions was an indirect and unexpected consequence of the fall of the Berlin Wall in 1989. (Andrew Baruch Wachtel 2006, pp. 1-2).

In his Prison Notebooks, pointing out the fact that not everyone who can occasionally fry a couple of eggs or sew a tear in a jacket is called a cook or a tailor, Antonio Gramsci insisted that "all men are intellectuals ... but not all men have in society the function of intellectuals." (Gramsci 1971, p. 9) Individual skills notwithstanding, it is the intellectuals' ability to attach a larger social significance to their esoteric professional skills that has usually turned them into a social group with a unique cultural role. Yet, neither the skills themselves nor their public representations remain unchanged throughout time, and Gramsci's famous distinction between "organic" and "traditional" intellectuals usefully highlights the root of the theoretical and sociological difficulty involved in analyzing the intellectuals as a specific stratum.

To recall, the main difference between the two groups has to do with two different models of temporality that structure their identities. Traditional intellectuals normally present themselves as a manifestation of "uninterrupted historical continuity" whose main social function is to preserve, reproduce, and transmit to 
new generations the cultural legacy that they inherited. Their identification with eternal values, timeless canons, and established forms of cultural interpretation, Gramsci emphasized, normally allows traditional intellectuals to assume a social position that is "autonomous and independent of the dominant social group" (Gramsci 1971 p. 7). Unlike self-sufficient traditional intellectuals, organic intellectuals are organized synecdochically — as a stratum (or several strata) whose main task and function is to provide a newly emerging economic class with "homogeneity and an awareness of its own function not only in the economic but also in the social and political fields" (Gramsci 1971, p. 5). Acting "here and now," organic intellectuals are mostly concerned with the present, using the past as a point of departure. In a somewhat simplified form, the perennial interplay between Gramsci's two types of cultural actors could be epitomized as the binary-priests vs. commissars.

Gramsci's sociology of intellectuals provides a useful entry into sociology of knowledge, too: his typology clearly delineates two forms of cultural production, the diachronic tradition, on the one hand, and synchronic innovation, on the other. In today's context, intellectuals' "traditionalism" often works as a synonym for their outsidedness in regard to the dominant (or popular) forms of knowledge and practices of knowledge production, while intellectuals" "organicism" frequently acquires the shape of various metaphors and practices of social and political "responsibility." 1 To put it somewhat differently: two temporal models of knowledge production have acquired a spatial dimension: disengagement ("outsidedness") and involvement ("responsibility") have become major forms of the intellectuals' existence.

The difference between organic and traditional forms of knowledge production helps us understand better the intellectuals' trajectories during and after the collapse of socialism. Created by the socialist state-either as its active supporter or as its underground opposition-the socialist intelligentsia combined, in a peculiar manner, appeals to traditional values and norms with a particular organic sensitivity that helped to infuse forms of the past with a contemporary content. The traditionalist trend was realized here not so much through the adherence to timeless canons but rather through reclaiming the timelessness of the ethical stance. Disassociation from the state and active engagement in moral critique were historically available forms of social activity for the intelligentsia that was not fully co-opted by the party state. This was clearly reflected in two main moral appeals of the late socialist period: Alexander Solženitsyn's negative imperative "Live not by lies" and Vaclav Havel's positive invitation "to live in truth" delineated a symbolic and moral space for practicing various forms of distancing from dominant social practices of late socialism. "Truth," "high culture," and "state" provided a conceptual configuration that triangulated the intelligentsia's existence during late socialism, just as ideas of "narod," "class," and "progress" determined the views of Russian intelligentsia throughout the nineteenth century. ${ }^{2}$

\footnotetext{
${ }^{1}$ For different versions of these approaches see correspondingly: Mojares (2006, pp. 381-530) and Maclean et al. (1990).

2 See e.g. Nahirny (1983, p. 6).
} 
Ironically, the intelligentsia's appeals to eternal values and its retreat into history emerged as a particular form of organic-here and now-response to the practices of late socialism. In various forms, the late socialist intelligentsia articulated a set of norms and models of behavior that might not have undermined state domination but have managed to increase significantly a sense of personal agency. Deprived of any serious form of control over cultural production and circulation, the intelligentsia of late socialism repositioned itself as the moral elite. Articulating a promise of morality in an immoral society became its main function.

The end of the cold war and the collapse of state socialism drastically altered the intelligentsia's claims to moral superiority. Advanced age, death, and the withdrawal from public activity of major east European intellectuals have played an important role in diminishing their impact on society and politics after the revolutionary changes of the late 1980s-early 1990s. Yet, as the articles collected in this volume show, the disappearance of the moral elite is also a reflection of changes that drastically transformed patterns of cultural production and structures of moral systems in the region. In a somewhat understated way, the essays demonstrate that the disappearance of norms, values, and practices cultivated and defended by the intelligentsia goes hand in hand with the disappearance of the intelligentsia as a distinctive social group. In short, we can no longer expect either a "new Milan Kundera" or a "new Andrei Sakharov". Highly fragmented and diversified, the new educated classes in post socialist eastern Europe choose strategies of professional existence and forms of cultural involvement that have very little in common with the two-century-long history of eastern European intelligentsia. In turn, increasingly differentiated post-socialist societies seem to be more concerned with the pragmatics of their social and economic restructuring rather than with the cultural or ideological homogenization that the intelligentsia traditionally offered.

This volume addresses precisely this dual process of the intelligentsia's decline as a significant social force and the erosion of values and practices that constituted the ideological and habitual core of the moral elite of late socialism. Written by sociologists, the articles in this volume are mostly concerned with practices and forms of their symbolization rather than with genealogies of ideas. Each essay traces a particular aspect of the transformation of late socialist intelligentsia into a nonsocialist actor. In some cases, this transformation entailed a complete departure from intellectual activities, in others it meant a radical reformatting of intellectual or artistic practices. What remains common in all these cases is a striking disappearance of the moral core that was so crucial for the intelligentsia of earlier periods. Appeals to universal truth and common values are replaced by group interests, professional codes, and identity politics.

The fragmentation of the intelligentsia and its cultural ethos is the main theme of Hanna Palska's study. Based on sociological interviews conducted in Poland during 1999-2007, Palska shows that the disappearance of the late socialist intelligentsia and its set of values does not necessarily imply that these values actually lost their attractiveness. Rather, as Palska convincingly suggests, these values and life-styles have become practically unsustainable in new market conditions. The downfall of the "substitute elite" is mostly determined by the collapse of the usual mechanisms through which this group has been reproducing itself for decades. Traditional forms 
of cultural involvement (reading, theater, exhibitions), through which the intelligentsia acquired its authority and its set of shared values, aesthetic predispositions, and affective scenarios could hardly compete with newly available forms of commodity-driven (shopping), experience-oriented (tourism), and escapist (entertainment) cultural consumption. Symptomatically, this shift from pedagogic to hedonistic cultural consumption also coincides with a radical shrinking of the scope of social engagement and public responsibility. The post-socialist segmentation of the public sphere results in new forms of social participation: the historical striving of the Polish intelligentsia to address and mobilize larger social groups ${ }^{3}$ is supplanted by a dominant preoccupation with one's own (middle) class belonging and professional affiliations.

This gentrification and individualization of late socialist intelligentsia and its post-socialist heirs are indeed hardly unusual: the rediscovery of privacy and family values is an expected reaction to the years of enforced collectivity. What seems to be somewhat new, though, is that this audacious individualism is not accompanied by any need to construct or, at least, to attempt to imagine social and cultural links that could bond the nation together. It appears that by casting off the coat of Konrad, i.e. by brushing aside any concerns about the nature of the social in a universal mould, the heirs of the late socialist intelligentsia simultaneously reveal the profound vacuity of the intelligentsia's primary professional function: Providing a sense of normative homogeneity and group self-awareness makes little sense in a fragmented society of individuals. Intellectuals disappear together with the function that brought them to life.

The development of the intelligentsia in post-soviet Belarus, described in the essay of Elena Gapova, presents an interesting contrast with the gentrification and individualization of the late socialist intelligentsia analyzed by Palska. The primacy of individual concerns, so striking in the Polish case, is still rudimentary in Belarus. What Gapova documents instead is a culture war of two different groups: Westernized intellectuals compete here with state-sponsored bureaucratic educators. To a large degree, the prominence of the collective is determined by institutionalized frameworks within which both groups exist. Bureaucratic educators would have been impossible without their administrative and financial power, which is ensured by their direct (and often monopolized) access to state resources and institutions. In turn, the social authority of westernized intellectuals comes almost entirely from their intellectual involvement with educational foundations and think tanks in the West and their western-style academic activity. As Gapova suggests, it is crucial not to mistake this struggle between the Soviet-style reproduction of bureaucratic elite and post-Soviet production of cultural capital(ists) for a traditional ideological confrontation between yet another generation of conservative Slavophiles and liberal Westernizers. Hardly claiming any universal significance, each group fights for vital symbolic (and financial) resources that could guarantee their survival. Gapova's essay outlines yet another important difference from the case of the Polish post-intelligentsia described by Palska. For intellectuals in Belarus the consumption paradise - be it intellectual or entirely materialistic - appears to be

\footnotetext{
3 See e.g. Iwańska (1998).
} 
more of a promise of the future rather than their everyday reality. It is not so much the actual enjoyment of consumption that replaces the intelligentsia's more traditional preoccupation with artistic and moral values in Belarus. Rather they seem to be more concerned with securing their unstable access to new forms of consumption. Even though they are organic intellectuals of sorts, neither group, however, can expect a financial or institutional stability. The formation of dominant classes has been stagnant in post-Soviet Belarus for more than a decade, and the unresolved culture war among two intellectual classes reflects precisely that: the country's frozen status quo.

The case of European University in St. Petersburg (EUSP) demonstrates how a very similar attempt to institutionalize forms of intellectual production could take place within a very different cultural and political context. As Zhuravlev, Kondov, and Savel'eva show, the university emerged at the intersection of two main trends: the individual striving for professional success was accompanied here by a clear understanding that such success would be impossible without creating an intellectually independent and financially autonomous educational institution. Not unlike a professional guild, the EUSP's intellectuals have become incorporated-as an organization of knowledge producers. As a result, the institutional setting acts as a place within which intellectuals could realize themselves and, simultaneously, as a mechanism that produces and confirms their professional identity. The function of the intellectuals and their institutional belonging become inseparable here.

The case presents yet another feature of cultural production that would have been impossible 20 years ago. As the authors of the essay stress, the educational success and the intellectual prestige of the EUSP are determined to a large extent by various forms of cultural arbitrage practiced by its faculty members. Professional careers are built through active and deliberate trading in incommensurable forms of cultural competency. In the process of this arbitrage, "western" forms of knowledge are commodified for the consumption by a domestic audience, while "the Russian take" on various issues is supplied for foreign consumers. Devoid of any primary-or, to be more precise, any dominant-constituency, this corporation of knowledge producers is a medium and a mediator that brings various economic, political, and intellectual forces together.

Finally, the essay by Alexandra Hrycak and Maria Rewakowicz weaves together several major themes that are discussed in this volume. The emergence of feminist groups and discourses in post-Soviet Ukraine demonstrates how the general fragmentation of post-socialist societies is compensated by forging new micropublics whose identities and languages were often a product of elaborate (and at times twisted) cultural translation. Two aspects of this translation seem to be especially striking. The first one is a strong contrast between the content and the organizational forms of feminist micro-publics described by Hrycak and Rewakowicz. Decidedly post-communist in its agenda, the structure of intellectual activity of Ukrainian feminists is reminiscent of the didactic campaigns of Soviet agitprop. In a way that recalls the old Leninist formula, feminist micro-publics are similarly concerned with being not only a collective propagandist and a collective agitator, but also a collective organizer. It is, perhaps, not surprising that these methods have yet to demonstrate their social effectiveness: as Hrycak and 
Rewakowicz persistently demonstrate, feminist macro-publics are most successful in such traditionally feminized fields as philological studies and literary criticism.

The second aspect of emerging micro-publics reflects the peculiar origin of gender and feminist studies as a scholarly field within the Ukrainian academia. Supported first of all by western governments and western private foundations, gender and feminist studies in the Ukraine have become a major source of nationalist and postcolonial thought. This version of postcoloniality, however, has very little in common with traditional subaltern studies that tend to privilege hybrid identities and de-centered subjectivities. In the Ukrainian version of postcolonialism actively promoted by a major feminist writer Oksana Zabuzhko, somatic nationalism replaced social constructivism and post-structuralism. Rooted in various metaphors of the body, such an organic image of the nation logically leads to a monolingual and monocultural version of the Ukrainian public. And it is indicative that in her attempts to revise the traditional literary canon Zabuzhko is more concerned with uncovering traces of what Hrycak and Rewakowicz describe as "a lost Ukrainian aristocratic tradition" than with opening up the democratic potential of forgotten or repressed cultures.

Certainly, the strategies of transformation of late socialist intelligentsia described by the authors of this volume do not exhaust all the possibilities present today in Eastern Europe. However, different as they are, these strategies point to the same sociological conclusion: the withering of the socialist state meant the end of its moral elite.

\section{References}

Gramsci, A. (1971). Selections from the Prison Notebooks (p. 9). New York: International Publisher. Iwańska, A. (1998). Polish Intelligentsia in Nazi concentration camps and American exile. Lewiston: The Edwin Mellen Press.

Maclean, I., Montefiore, A., \& Winch, P. (Eds.). (1990). The political responsibility of intellectuals. Cambridge: Cambridge University Press.

Mojares, R. B. (2006). Brains of the Nation: Pedro Paterno, T.H. Pardo de Tavera, Isabelo de los Reyes and the production of modern knowledge (pp. 381-530). Quezon City: Ateneo de Manila University Press.

Nahirny, V. C. (1983). The Russian intelligentsia: From torment to silence (p. 6). New Brunswick: Transaction books.

Wachtel, A. B. (2006). Remaining relevant after communism: The role of the writer in eastern Europe (pp. 1-2). Chicago: The University of Chicago Press. 